\title{
Pengaruh Kesadaran WP, Kualitas Pelayanan, Sanksi Pajak dan Penerapan Tapping Box pada Kepatuhan WP Restoran
}

\author{
Putu Nanda Bagus Kresna Yudha ${ }^{1}$ \\ Fakultas Ekonomi dan Bisnis \\ Universitas Udayana, Indonesia \\ Email: nandabagus95@gmail.com
}

\author{
Putu Ery Setiawan ${ }^{2}$ \\ Fakultas Ekonomi dan Bisnis \\ Universitas Udayana, Indonesia
}

\begin{abstract}
ABSTRAK
Penelitian ini bertujuan untuk memberikan bukti empiris tentang pengaruh kesadaran wajib pajak, kualitas pelayanan, sanksi pajak dan penerapan alat perekam transaksi (tapping box) terhadap kepatuhan wajib pajak dalam membayar pajak restoran. Penelitian ini dilakukan pada perusahaan yang telah terdaftar di Badan Pendapatan Daerah Kota Denpasar sejak tahun 2017. Sampel pada penelitianini adalah restoran yang telah dipasangi alat tapping box. Metode penentuan sampel menggunakan metode purposive sampling dengan menggunakan rumus slovin sehingga diperoleh 31 perusahaan sebagai sampel. Pengumpulan data menggunakan kuesioner. Teknik analisis data yang digunakan adalah analisis regresi linier berganda. Hasil pengujian hipotesis menunjukan bahwa variabel kesadaran wajib pajak, kualitas pelayanan, sanksi perpajakan, dan penerapan tapping box berpengaruh positif terhadap kepatuhan wajib pajak alam membayar pajak restoran di Badan Pendapatan Daerah Kota Denpasar.
\end{abstract}

Kata Kunci: Kesadaran Wajib Pajak; Kualitas Pelayanan; Sanksi Pajak; Penerapan Tapping Box; Kepatuhan Wajib Pajak.

\section{Taxpayer Awareness, Service Quality, Tax Sanctions and Application of Tapping boxes on Restaurant Taxpayer Compliance}

\section{ABSTRACT}

This study aims to provide empirical evidence about the influence of taxpayer awareness, service quality, tax sanctions and the application of transaction recording devices (tapping boxes) to taxpayer compliance in paying restaurant taxes. This research was conducted on companies that have been registered with the Denpasar City Revenue Agency since 2017. The sample in this study is a restaurant that has been installed with a taping box. The method of determining the sample using a purposive sampling method using the Slovin formula to obtain 31 companies as samples. Data collection using a questionnaire. The data analysis technique used is multiple linear regression analysis. The results of hypothesis testing show that the variable of taxpayer awareness, service quality, tax sanctions, and the application of tapping boxes has a positive effect on the compliance of natural taxpayerspaying restaurant taxes at the Denpasar City Revenue Agency.

Keywords: $\quad$ Awareness of Taxpayers; Service Quality; Tax Sanctions; The Application Of Tapping boxes; Taxpayer Compliance.

The Article is Available in: https://ojs.unud.ac.id/index.php/Akuntansi/index 


\section{PENDAHULUAN}

Pajak sebagai salah satu sumber penerimaan negara memiliki peran yang sangat besar dan semakin diandalkan dalam kepentingan pembangunan serta membiayai pengeluaran pemerintah (Pratiwi \& Setiawan, 2014). Pembangunan disegala bidang dan berjalannya roda pemerintahan banyak dibiayai dari sektor pajak. Pajak dapat dikatakan sebagai penyumbang penerimaan terbesar bagi pemerintah pusat maupun daerah. Hampir seluruh daerah di Indonesia menggali potensi pendapatannya melalui pajak daerah. Untuk itu pemerintah daerah harus mampu meningkatkan sumber potensi pendapatan daerahnya (Susilawati \& Budiartha, 2013).

Kesadaran wajib pajak merupakan faktor penting dalam sistem perpajakan modern (Harahap, 2004). Peningkatan kesadaran masyarakat dalam memenuhi kewajiban perpajakannya dapat dibentuk dengan memberikan penyuluhan kepada wajib pajak bahwa pajak tersebut sangat penting bagi penerimaan pendapatan daerah demi menunjang kesejahteraan masyarakat sehingga dapat terbentuknya pemahaman dari masyarakat tentang hak dan kewajiban yang dimilikinya sesuai dengan peraturan peundang-undangan perpajakan yang berlaku. Apabila kesadaran wajib pajak meningkat maka kepatuhan wajib pajak akan meningkat (Nugroho, Andini, \& Raharjo, 2016). Tingkat kepatuhan pelaporan pajak akan lebih tinggi ketika wajib pajak memiliki tanggung jawab moral yang lebih kuat (Januarta, 2011).

Faktor lain yang mempengaruhi kepatuhan wajib pajak adalah kualitas pelayanan. Peningkatan kualitas pelayanan merupakan suatu kegiatan atau menciptakan secara sengaja atau terarah untuk memberi kemudahan kepada masyarakat. Menurut (Hanousek \& Palda, 2004) kemauan wajib pajak untuk membayar pajak sebagian besar dipengaruhi oleh kualitas pelayanan yang diberikan oleh pemerintah. Semakin baik kualitas pelayanan yang diberikan oleh petugas dalam melayani wajib pajak maka akan semakin nyaman wajib pajak membayar pajaknya, dengan kualitas pelayanan yang baik akan mendorong seseorang untuk memenuhi kewajibannya didalam membayar pajak.

Peningkatan kualitas dan kuantitas pelayanan diharapkan dapat meningkatkan kepuasan pada wajib pajak sebagai pelanggan sehingga meningkatkan kepatuhan dalam bidang perpajakan (Supadmi, 2011). Pelayanan yang berkualitas bukan hanya pelayanan yang diberikan oleh fiskus saja tetapi melainkan pelayanan didalam ruangan seperti kenyaman dalam melakukan kewajibannya dan kenyaman semua fasilitas yang disediakan oleh kantor pembayaran pajak masing-masing.

Pajak restoran merupakan salah satu penyumbang terbesar terhadap Pendapatan Asli Daerah (PAD). Walaupun pada dasarnya pemunggutan pajak bersifat self assessment yaitu wajib pajak yang menghitung dan melaporkan sendiri ke badan Pendapatan Daerah. Dalam penerapannya seringkali menimbulkan terjadinya tindakan-tindakan yang tidak diiginkan, sehingga sistem pemunggutan self assessment perlu ditunjang dengan sistem monitoring online Pajak Restoran di suatu daerah. Penggunaan sistem monitoring online ini akan lebih memudahkan Badan Pendapatan daerah untuk mendapatkan gambaran mengenai potensi pendapatan pajak restoran. Sistem monitoring online 
yang digunakan di Badan Pendapatan Daerah Kota Denpasar disebut dengan perangkat pemantau transaksi yang dikenal dengan tapping box.

Perangkat tapping box akan menangkap data yang dikirimkan dari mesin kasir ke printer dan kemudian mengirimkannya melalui jaringan GSM ke server Badan Pendapatan Daerah Kota Denpasar. Aplikasi pengolah data dan pelaporan setidaknyaa akan menampilkan laporan rekap transaksi dan pajaknya secara total maupun masing-masing wajib pajak. Kegiatan pemasasangan tapping box mulai dilakukan sejak bulan November 2016 dan dari 95 wajib pajak yang telah di survei sebanyak 75 wajib pajak yang telah di pasang alat tapping box adalah terdiri dari 30 wajib pajak restoran dan 45 wajib pajak restoran. Pemasangan alat ini belum dapat dilakukan pada semua restoran ataupun restoran yang ada di Kota Denpasar disebabkan oleh minimnya ketersediaan anggaran dan jumlah SDM yang terbatas (Denpasar, 2016).

James \& Nobes (1997) menyatakan bahwa tidak satupun sistem perpajakan dapat berfungsi dengan efektif tanpa peran serta wajib pajak, karena itu faktor-faktor yang mempengaruhi kepatuhan pajak sangatlah penting. Penelitian ini dilakukan untuk menguji kembali pengaruh kesadaran, kualitas pelayanan, sanksi pajak dan penerapan alat perekam transaksi (tapping box) pada kepatuhan wajib pajak restoran di Badan Pendapatan Daerah Kota Denpasar. Kontradiksi dan inkonsistensi pada penelitian-penelitian terdahulu membuat penelitian ini masih menarik untuk dilakukan.

Tujuan dari penelitian ini adalah untuk memeroleh bukti empiris pengaruh kesadaran wajib pajak pada kepatuhan wajib pajak dalam membayar Pajak Restoran di Badan Pendapatan Daerah Kota Denpasar, untuk memeroleh bukti empiris pengaruh kualitas pelayanan pada kepatuhan wajib pajak dalam membayar Pajak Restoran di Badan Pendapatan Daerah Kota Denpasar, untuk memeroleh bukti empiris pengaruh sanksi pajak pada kepatuhan wajib pajak dalam membayar Pajak Restoran di Badan Pendapatan Daerah Kota Denpasar dan untuk memeroleh bukti empiris pengaruh penerapan alat perekam transaksi (tapping box) berpengaruh pada kepatuhan wajib pajak dalam membayar Pajak Restoran di Badan Pendapatan Daerah Kota Denpasar.

Behavioral beliefs adalah keyakinan individu akan hasil dari suatu perilaku dan evaluasi atas hasil tersebut (Mustikasari, 2007). Kesadaran akan hasil dari suatu perilaku wajib pajak dapat mempengaruhi adanya kesadaran wajib pajak untuk berperilaku patuh. Semakin tinggi tingkat kesadaran wajib pajak, maka pemahaman dan pelaksanaan kewajiban perpajakan semakin baik sehingga dapat meningkatkan kepatuhan (Dewinta \& Syafruddin, 2012). Berdasarkan literatur dan hasil penelitian sebelumnya, maka dapat dirumuskan hipotesis sebagai berikut.

$\mathrm{H}_{1}$ : Kesadaran wajib pajak berpengaruh positif pada kepatuhan wajib pajak dalam membayar pajak restoran.

Behavioral beliefs adalah keyakinan individu akan hasil dari suatu perilaku dan evaluasi atas hasil tersebut (Mustikasari, 2007). Keyakinan akan hasil dan evaluasi dari suatu perilaku wajib pajak dapat dipengaruhi adanya kualitas pelayanan. Peningkatan kualitas pelayanan merupakan suatu kegiatan atau menciptakan secara sengaja atau terarah untuk memberi kemudahan kepada masyarakat (Febrianti, 2018). Kemauan wajib pajak untuk membayar pajak 
sebagian besar dipengaruhi oleh kualitas pelayanan yang diberikan oleh pemerintah. Semakin bagus kualitas pelayanan yang diberikan oleh fiskus dalam melayani wajib pajak maka akan semakin nyaman wajib pajak membayar pajaknya, dengan kualitas pelayanan yang baik akan mendorong seseorang untuk memenuhi kewajibannya didalam membayar pajak. Peningkatan kualitas dan kuantitas pelayanan diharapkan dapat meningkatkan kepuasan pada wajib pajak sebagai pelanggan sehingga meningkatkan kepatuhan dalam bidang perpajakan (Jotopurnomo \& Mangoting, 2013).

$\mathrm{H}_{2}$ : Kualitas pelayanan berpengaruh positif pada kepatuhan wajib pajak dalam membayar pajak restoran.

Normative beliefs adalah keyakinan tentang harapan normatif orang lain dan motivasi untuk memenuhi harapan tersebut (Mustikasari, 2007). Motivasi wajib pajak untuk berperilaku patuh dapat ditingkatkan dengan adanya sanski pajak. Menurut (Mardiasmo, 2016), sanksi perpajakan merupakan jaminan bahwa ketentuan peraturan perundang-undangan perpajakan (norma perpajakan) akan dituruti atau dipatuhi, dengan kata lain sanksi perpajakan merupakan alat pencegah (preventif) agar wajib pajak tidak melanggar norma perpajakan

$\mathrm{H}_{3}$ : Sanksi pajak berpengaruh positif pada kepatuhan wajib pajak dalam membayar pajak restoran.

Control Beliefs merupakan keyakinan individu tentang keberadaan hal-hal yang mendukung atau menghambat perilakunya dan persepsinya tentang seberapa kuat hal-hal tersebut mempengaruhi perilakunya. Menurut (Rahmani, 2014), tanggung jawab atas kewajiban pembayaran pajak sebagai pencerminan kewajiban kenegaraan di bidang perpajakan berada pada anggota masyarakat sendiri untuk memenuhi kewajiban tersebut. Hal tersebut sesuai dengan self assessment system yang dianut dalam sistem perpajakan di Indonesia, tetapi seringkali menimbulkan terjadinya tindakan-tindakan yang tidak diiginkan, sehingga sisitem pemunggutan self assessment perlu ditunjang dengan sistem monitoring Online. Penggunaan sistem monitoring online ini akan lebih memudahkan Badan Pendapatan daerah untuk mendapatkan gambaran mengenai potensi pendapatan pajak restoran. Sistem monitoring online yang digunakan di Badan Pendapatan Daerah Kota Denpasar disebut dengan perangkat pemantau transaksi yang dikenal dengan Tapping box.

Perangkat tapping box diperlukan untuk menangkap data yang dicetak oleh printer receipt yang ditempatkan diantara mesin kasir dan printer. Perangkat tapping box akan menangkap data yang dikirimkan dari mesin kasir ke printer dan kemudian mengirimkannya melalui jaringan GSM ke server Badan Pendapatan Daerah Kota Denpasar. Penerapan alat perekam transaksi (tapping box) sangat efektif di dalam mengurangi terjadinya kecurangan terhadap pelaporan pajak. Hal ini karena alat ini mampu memberikan gambaran yang lebih detail terhadap jumlah pajak yang harus dibayarkan oleh wajib pajak dan akan berdampak signifikan terhadap penerimaan pajak daerah. Penerapan tapping box akan meningkatkan kepatuhan wajib pajak dalam membayar pajak, maka dapat dirumuskan hipotesis sebagai berikut:

$\mathrm{H}_{4}$ : Penerapan alat perekam transaksi (tapping box) berpengaruh positif pada kepatuhan wajib pajak dalam membayar pajak restoran. 
Penelitian ini mengkaji pengaruh kesadaran wajib pajak, kualitas pelayanan, sanksi pajak, dan penerapan alat perekam transaksi (tapping box) pada kepatuhan wajib pajak dalam membayar pajak restoran di Badan Pendapatan Daerah Kota Denpasar.

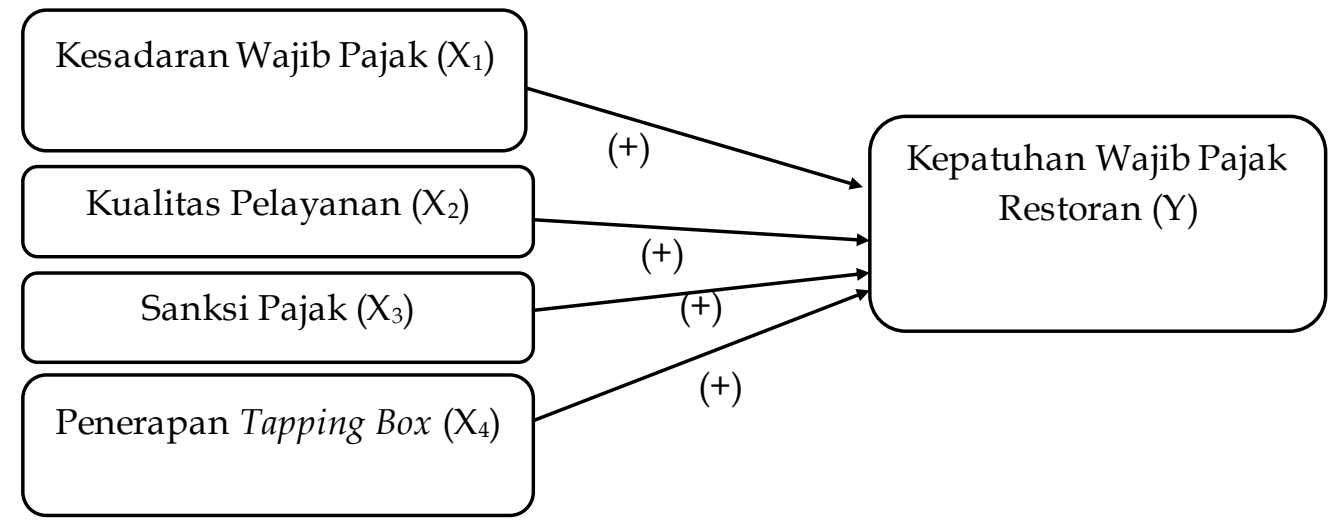

Gambar 1. Model Penelitian

Sumber: Data Penelitian, 2019

\section{METODE PENELITIAN}

Penelitian ini dilakukan pada restoran yang telah terdaftar di Badan Pendapatan Daerah Kota Denpasar sejak tahun 2017. Sampel pada penelitian ini adalah restoran yang telah dipasangi alat tapping box. Metode penentuan sampel menggunakan metode purposive sampling dengan menggunakan Rumus Slovin sehingga diperoleh 31 perusahaan sebagai sampel. Pengumpulan data menggunakan kuesioner. Teknik analisis data yang digunakan adalah analisis regresi linier berganda. Objek penelitian ini adalah kepatuhan wajib pajak dalam membayar pajak di Dinas Pendapatan Daerah Kota Denpasar. Data yang diperoleh kemudian diolah menggunakan SPSS 22. Hasil analisis dinyatakan dalam bentuk persamaan regresi linear berganda sebagi berikut (Sugiyono, 2016):

$\mathrm{Y}=\alpha+\beta_{1} X_{1}+\beta_{2} X_{2}+\beta_{3} X_{3}+\beta_{4} X_{4}+\varepsilon$

Keterangan:

$\mathrm{Y} \quad=$ Kepatuhan wajib pajak restoran

$\mathrm{a} \quad=$ Konstanta

$\beta_{1} \quad=$ Koefisien regresi dari kesadaran wajib pajak $\left(X_{1}\right)$

$\beta_{2} \quad=$ Koefisien regresi dari kualitas pelayanan $\left(X_{2}\right)$

$\beta_{3} \quad=$ Koefisien regresi dari sanksi pajak $\left(X_{3}\right)$

$\beta_{4} \quad=$ Koefisien regresi dari penerapan Tapping box $\left(\mathrm{X}_{4}\right)$

$\mathrm{X}_{1} \quad=$ Kesadaran wajib pajak

$\mathrm{X}_{2}=$ Kualitas pelayanan

$X_{3} \quad=$ Sanksi pajak

$\mathrm{X}_{4} \quad=$ Penerapan alat perekam transaksi (Tapping box)

$\varepsilon \quad=$ error 


\section{HASIL DAN PEMBAHASAN}

Berdasarkan hasil olahan SPSS 22 yang meliputi variabel kesadaran wajib pajak, kualitas pelayanan, sanksi pajak, penerapan alat perekam tansaksi dan kepatuhan wajib pajak, didapat hasil analisis data untuk statistik deskriptif yang dapat dilihat pada Tabel 1.

\section{Tabel 1. Hasil Analisis Deskriptif}

\begin{tabular}{llllll}
\hline Variabel & $\mathrm{N}$ & Minimum & Maximum & Mean & Std. Deviation \\
\hline X1 & 31 & 6,00 & 21,23 & 16,2135 & 5,37012 \\
X2 & 31 & 4,00 & 14,94 & 11,2103 & 3,48251 \\
X3 & 31 & 4,00 & 14,32 & 10,5665 & 3,54287 \\
X4 & 31 & 3,00 & 11,81 & 8,8810 & 2,48136 \\
Y & 31 & 3,00 & 10,83 & 8,1613 & 2,72119 \\
Valid N (listwise) & 31 & & & & \\
\hline
\end{tabular}

Sumber: Data Penelitian, 2019

Berdasarkan statistik deskriptif yang ditunjukkan Tabel 1, digunakan nilai terendah dari kesadaran wajib pajak sebesar 6,00 dan nilai tertinggi sebesar 21,23. Nilai rata-rata dari kesadaran wajib pajak adalah 16,2135. Ini menunjukkan bahwa nilai rata-rata variabel kesadaran wajib pajak mendekati nilai maksimum daripada nilai minimumnya. Hal ini menandakan bahwa rata-rata kesadaran wajib pajak. Nilai standar deviasi sebesar 5,37012 yang tidak melebihi dua kali rata-ratanya menunjukkan bahwa rentang antara nilai terendah dengan nilai tertinggi tidak terlalu jauh, artinya responden cenderung setuju bahwa kesadaran wajib pajak dalam kondisi baik.

Nilai terendah dari kualitas pelayanan sebesar 4,00 dan nilai tertinggi sebesar 14,94. Nilai rata-rata dari kualitas pelayanan adalah 11,2103. Ini menunjukkan bahwa nilai rata-rata variabel kualitas pelayanan mendekati nilai maksimum daripada nilai minimumnya. Hal ini menandakan bahwa rata-rata kesadaran wajib pajak. Nilai standar deviasi sebesar 3,48251 yang tidak melebihi dua kali rata-ratanya menunjukkan bahwa rentang antara nilai terendah dengan nilai tertinggi tidak terlalu jauh, artinya responden cenderung setuju bahwa kualitas pelayanan dalam kondisi baik.

Nilai terendah dari sanksi pajak sebesar 4,00 dan nilai tertinggi sebesar 14,32. Nilai rata-rata dari sanksi pajak adalah 10,5665. Ini menunjukkan bahwa nilai rata-rata variabel sanksi pajak mendekati nilai maksimum daripada nilai minimumnya. Hal ini menandakan bahwa rata-rata sanksi pajak. Nilai standar deviasi sebesar 3,54287 yang tidak melebihi dua kali rata-ratanya menunjukkan bahwa rentang antara nilai terendah dengan nilai tertinggi tidak terlalu jauh, artinya responden cenderung setuju bahwa sanksi pajak telah diterappkan dengan baik.

Nilai terendah dari penerapan alat perekam transaksi sebesar 3,00 dan nilai tertinggi sebesar 11,81 . Nilai rata-rata dari penerapan alat perekam transaksi adalah 8,8810. Ini menunjukkan bahwa nilai rata-rata variabel penerapan alat perekam transaksi mendekati nilai maksimum daripada nilai minimumnya. Hal ini menandakan bahwa rata-rata penerapan alat perekam transaksi. Nilai standar deviasi sebesar 2,48136 yang tidak melebihi dua kali rata-ratanya menunjukkan bahwa rentang antara nilai terendah dengan nilai tertinggi tidak terlalu jauh, 
artinya responden cenderung setuju bahwa penerapan alat perekam transaksi dalam kondisi baik.

Nilai terendah dari kepatuhan wajib pajak sebesar 3,00 dan nilai tertinggi sebesar 10,83. Nilai rata-rata dari kepatuhan wajib pajak adalah 8,1613 . Ini menunjukkan bahwa nilai rata-rata variabel penerapan alat perekam transaksi mendekati nilai maksimum daripada nilai minimumnya. Hal ini menandakan bahwa rata-rata kepatuhan wajib pajak. Nilai standar deviasi sebesar 2,72119 yang tidak melebihi dua kali rata-ratanya menunjukkan bahwa rentang antara nilai terendah dengan nilai tertinggi tidak terlalu jauh, artinya responden cenderung setuju bahwa kepatuhan wajib pajak dalam kondisi baik.

Pengujian validitas dilakukan dengan menghitung nilai Pearson Correlation. Jumlah item dalam kuesioner ini adalah sebanyak 20 item. Tabel 2, menyajikan hasil uji validitas instrumen penelitian sebagai berikut.

Tabel 2. Hasil Uji Validitas

\begin{tabular}{lll}
\hline Variabel & $R_{\text {hitung }}$ & Keterangan \\
\hline Kesadaran wajib pajak & $0,836-0,921$ & Valid \\
Kualitas pelayanan & $0,775-0,917$ & Valid \\
Sanksi pajak & $0,865-0,916$ & Valid \\
Penerapan alat perekam transaksi & $0,753-0,871$ & Valid \\
Kepatuhan wajib pajak & $0,866-0,947$ & Valid \\
\hline
\end{tabular}

Sumber: Data Penelitian, 2019

Berdasarkan Tabel 2, dapat dilihat bahwa instrumen penelitian yang terdiri dari item-item pertanyaan budaya kesadaran wajib pajak, kualitas pelayanan, sanksi pajak, penerapan alat perekam tansaksi dan kepatuhan wajib pajak adalah valid. Hal ini dikarenakan korelasi antara skor masing-masing pertanyaan dengan skor total besarnya diatas 0,30 .

Uji reliabilitas menggunakan Cronbach Alpha dengan kriteria pengambilan keputusan sebagaimana dinyatakan oleh (Ghozali, 2009), yaitu jika koefisien Cronbach Alpha> 0,7 maka pernyataan dinyatakan andal, sebaliknya apabila nilai koefisien Cronbach Alpha <0,7 maka pernyataan dinyatakan tidak andal. Hasil uji reliabilitas pada penelitian ini disajikan pada Tabel 3.

Tabel 3. Hasil Uji Reliabilitas

\begin{tabular}{lll}
\hline Variabel & Cronbach Alpha & Keterangan \\
\hline Kesadaran wajib pajak & 0,950 & Reliabel \\
Kualitas pelayanan & 0,893 & Reliabel \\
Sanksi pajak & 0,908 & Reliabel \\
Penerapan alat perekam transaksi & 0,764 & Reliabel \\
Kepatuhan wajib pajak & 0,890 & Reliabel \\
\hline
\end{tabular}

Sumber: Data Penelitian, 2019

Berdasarkan hasil uji reliabilitas yang disajikan dalam Tabel 3. dapat disimpulkan bahwa variabel-variabel yang digunakan dalam penelitian ini adalah reliabel karena keseluruhan variabel memiliki Cronbach's Alpa yang lebih dari 0,70, sehingga layak digunakan menjadi alat ukur instrumen kuesioner dalam penelitian ini.

Analisis regresi digunakan untuk melihat pengaruh variabel bebas pada variabel terikat. Berdasarkan Tabel 4, dapat diringkas model persamaan regresi linear bergandanya sebagai berikut: 


$$
Y=-2,884+0,153 X_{1}+0,263 X_{2}+0,262 X_{3}+0,322 X_{4}+\varepsilon
$$

Nilai konstanta sebesar $-2,844$ menunjukkan bahwa variabel kesadaran wajib pajak, kualitas pelayanan, sanksi pajak, penerapan alat perekam tansaksi sama dengan nol (tetap atau tidak berubah), menyebabkan kepatuhan wajib pajak akan menurun sebesar konstantanya. Nilai koefisien beta dari variabel kesadaran wajib pajak bernilai positif yang berarti bahwa semakin tinggi kesadaran wajib pajak, menyebabkan semakin meningkat kepatuhan wajib pajak. Nilai koefisien beta dari variabel kualitas pelayanan bernilai positif yang berarti bahwa semakin tinggi kualitas pelayanan, menyebabkan semakin meningkat kepatuhan wajib pajak. Nilai koefisien beta dari variabel sanksi pajak bernilai positif yang berarti bahwa semakin tinggi sanksi pajak, menyebabkan semakin meningkat kepatuhan wajib pajak. Nilai koefisien beta dari variabel penerapan alat perekam transaksi bernilai positif yang berarti bahwa semakin tinggi penerapan alat perekam transaksi, menyebabkan semakin meningkat kepatuhan wajib pajak.

Tabel 4. Hasil Analisis Regresi Linear Berganda

\begin{tabular}{|c|c|c|c|c|c|}
\hline \multirow[t]{2}{*}{ Model } & \multicolumn{2}{|c|}{ Unstandardized Coefficients } & Standardized Coefficients & \multirow[t]{2}{*}{$\bar{t}$} & \multirow[t]{2}{*}{ Sig. } \\
\hline & $\bar{B}$ & Std. Error & Beta & & \\
\hline (Constant) & $-2,884$ & 1,451 & & $-1,987$ & 0,058 \\
\hline $\mathrm{X}_{1}$ & 0,153 & 0,058 & 0,302 & 2,651 & 0,013 \\
\hline $\mathrm{X}_{2}$ & 0,263 & 0,094 & 0,337 & 2,800 & 0,010 \\
\hline $\mathrm{X}_{3}$ & 0,261 & 0,086 & 0,340 & 3,031 & 0,005 \\
\hline $\mathrm{X}_{4}$ & 0,322 & 0,132 & 0,293 & 2,444 & 0,022 \\
\hline \multicolumn{2}{|c|}{ Adjusted R Square } & 0,654 & & & \\
\hline \multicolumn{2}{|l|}{ Sig. F } & 0,000 & & & \\
\hline
\end{tabular}

Sumber: Data Penelitian, 2019

Hasil analisis menunjukkan nilai Adjusted Rsquare sebesar 0,654. Ini berarti perubahan yang terjadi pada kepatuhan wajib pajak dapat dijelaskan oleh kesadaran wajib pajak, kualitas pelayanan, sanksi pajak dan penerapan alat perekam tansaksi sebesar 65,4 persen, sedangkan sisanya 34,6 persen dijelaskan oleh faktor lain yang tidak diuji dalam penelitian ini. Uji kelayakan model bertujuan untuk menguji apakah model yang digunakan dalam penelitian ini layak untuk digunakan atau tidak (Ghozali, 2009). Berdasarkan Tabel 4, nilai signifikansi $F$ atau $p$-value sebesar 0,000 yang kurang dari nilai $a=0,05$. Hal ini menunjukkan bahwa regresi ini layak digunakan sebagai alat analisis untuk menguji pengaruh variabel bebas pada variabel terikat.

Nilai koefisien regresi untuk variabel kesadaran wajib pajak sebesar 0,153 dengan tingkat signifikansi sebesar $0,013<0,05$, maka $\mathrm{H}_{1}$ diterima. Hal ini mengindikasikan bahwa kesadaran wajib pajak berpengaruh positif dan siginifikan terhadap kepatuhan wajib pajak. Nilai koefisien regresi untuk variabel kualitas pelayanan sebesar 0,263 dengan tingkat signifikansi sebesar $0,010<0,05$, maka $\mathrm{H}_{2}$ diterima. Hal ini mengindikasikan bahwa kualitas pelayanan berpengaruh positif dan siginifikan terhadap kepatuhan wajib pajak. Nilai koefisien regresi untuk variabel sanksi pajak sebesar 0,261 dengan tingkat signifikansi sebesar 0,005 $<0,05$, maka $\mathrm{H}_{3}$ diterima. Hal ini mengindikasikan bahwa sanksi pajak berpengaruh positif dan siginifikan terhadap kepatuhan wajib pajak. Nilai koefisien regresi untuk variabel penerapan alat perekam 
transaksi sebesar 0,322 dengan tingkat signifikansi sebesar 0,022 $<0,05$, maka $\mathrm{H}_{4}$ diterima. Hal ini mengindikasikan bahwa penerapan alat perekam transaksi berpengaruh positif dan siginifikan terhadap kepatuhan wajib pajak.

Hasil pengujian atas hipotesis pertama $\left(\mathrm{H}_{1}\right)$ dalam penelitian ini menunjukan bahwa kesadaran wajib pajak berpengaruh pada kepatuhan wajib pajak dalam membayar pajak restoran dengan signifikansi 0,013 <0,05. Hasil analisis regresi menunjukan bawah kesadaran wajib pajak berpengaruh positif pada kepatuhan wajib pajak dalam membayar pajak restoran. Hal ini menunjukan bahwa semakin tinggi tingkat kesadaran wajib pajak untuk membayar pajak maka semakin tinggi pula tingkat kepatuhan wajib pajak tersebut. Hasil Penelitian ini memperkuat teori Theory of Planned Behavior, yaitu Behavior Beliefs mengenai keyakinan individu akan hasil dari suatu perilaku dan evaluasi dari suatu perilaku wajib pajak atas adanya kesadaran wajib pajak dalam membayar pajak yang merupakan kontribusi terhadap dareah. Kesadaran wajib pajak menggambarkan individu-individu yang taat dalam membayarkan pajak khususnya dalam penelitian ini adalah pajak restoran. Kesadaran akan hasil dari suatu perilaku wajib pajak dapat memengaruhi adanya kesadaran wajib pajak untuk berperilaku patuh. Hasil penelitian ini konsisten dengan penelitian sebelumnya yakni, (Dewinta \& Syafruddin, 2012) semakin tinggi tingkat kesadaran wajib pajak, maka pemahaman dan pelaksanaan kewajiban perpajakan semakin baik sehingga dapat meningkatkan kepatuhan.

Hasil pengujian atas hipotesis kedua $\left(\mathrm{H}_{2}\right)$ dalam penelitian ini menunjukan bahwa kualitas pelayanan berpengaruh pada kepatuhan wajib pajak dalam membayar pajak restoran dengan signifikansi 0,010<0,05. Hasil analisis regresi menunjukan bahwa kualitas pelayanan berpengaruh positif pada kepatuhan wajib pajak dalam membayar pajak restoran. Hal ini menunjukan bahwa semakin baik kualitas pelayanan maka akan meningkatkan kepatuhan wajib pajak dalam membayarkan pajak restoran. Hasil Penelitian ini memperkuat teori theory of planned behavior, yaitu behavior beliefs mengenai keyakinan individu akan hasil dari suatu perilaku dan evaluasi dari suatu perilaku wajib pajak dapat dipengaruhi adanya kualitas pelayanan. Kemauan wajib pajak restoran untuk membayar pajak sebagian besar dipengaruhi oleh kulitas pelayanan yang diberikan oleh pemerintah. Data penerimaan Pajak Retoran pada Tabel 1, menunjukan terjadinya peningkatan penerimaan Pajak Restoran dari tahun 2013 sampai dengan 2017. Dengan kualitas pelayanan yang kaitannya dengan perpajakan yang dilakukan oleh petugas pajak maka akan membuat wajib pajak merasa lebih diperdulikan ataupun diperhatikan sehingga wajib pajak akan menjadi lebih patuh dalam membayar pajak. Hasil penelitian ini konsisten dengan penelitian sebelumnya yang dilakukan oleh (Sucandra \& Supadmi, 2016) menyatakan Wajib pajak yang mendapatkan pelayanan dengan kualitas yang baik akan senantiasa merasa senang, merasa puas atas pemberian pelayanan yang diberikan petugas pajak karena wajib pajak dapat memperoleh kemudahan dalam menyelesaikan dan melaksanakan seluruh hak dan kewajibannya sebagai wajib pajak sehingga kepatuhan wajib pajak dalam memenuhi kewajibannya meningkat.

Hasil pengujian atas hipotesis ketiga $\left(\mathrm{H}_{3}\right)$ dalam penelitian ini menunjukan bahwa sanksi pajak berpengaruh pada kepatuhan wajib pajak 
dalam membayar pajak restoran dengan signifikansi 0,005 $<0,05$. Hasil analisis regresi menunjukan bawah sanksi pajak berpengaruh positif pada kepatuhan wajib pajak dalam membayar pajak restoran. Hal ini menunjukan bahwa semakin berat sanksi yang diberikan atas pelanggaran pajak maka akan meningkatkan kepatuhan wajib pajak dalam membayarkan pajak restoran. Hasil Penelitian ini memperkuat theory planned of behavior yaitu behavior believe yang menyatakan keyakinan individu akan hasil yaitu sanksi perpajakan. Sanksi pajak merupakan alat pencegah (preventif) agar wajib pajak restoran tidak melanggar norma perpajakan sehingga legitimasi wajib pajak di Badan Pendapatan Daerah Kota Denpasar. Sanksi pajak sendiri merupakan sebuah teguran atau hukuman kepada wajib pajak yang merupakan tindakan nyata dari sebuah ketegasan dan keseriusan yang dilakukan oleh petugas pajak kepada wajib pajak yang melanggar aturan perpajakan yang berlaku. Hasil penelitian ini mendukung hasil penelitian yang dilakukan oleh (Dewi \& Merkusiwati, 2018) menyatakan bahwa Sanksi perpajakan berpengaruh postif terhadap kepatuhan pelaporan wajib pajak, serta mendukung salah satu literatur yang ditulis oleh (Mardiasmo, 2016), sanksi perpajakan merupakan jaminan bahwa ketentuan peraturan perundang-undangan perpajakan (norma perpajakan) akan dituruti atau dipatuhi, dengan kata lain sanksi perpajakan merupakan alat pencegah (preventif) agar wajib pajak tidak melanggar norma perpajakan.

Hasil pengujian atas hipotesis keempat $\left(\mathrm{H}_{4}\right)$ dalam penelitian ini menunjukan bahwa tapping box berpengaruh pada kepatuhan wajib pajak dalam membayar pajak restoran dengan signifikansi $0,022<0,05$. Hasil analisis regresi menunjukan bawah tapping box berpengaruh positif pada kepatuhan wajib pajak dalam membayar pajak restoran. Hal ini menunjukan tapping box memiliki peran yang sangat penting dalam meningkatkan kepatuhan wajib pajak dalam membayar pajak restoran. Hasil Penelitian ini memperkuat theory planned of behavior yaitu control beliefs yang merupakan keyakinan individu tentang keberadaan hal-hal yang mendukung atau menghambat perilakunya dan persepsinya tentang seberapa kuat hal-hal tersebut memengaruhinya. Tapping box sendiri dirasa sangat efektif dalam peranannya membuat wajib pajak menjadi taat dalam membayar pajak karena tapping box sendiri mempunyai fungsi merekam dan mencatat seluruh transaksi yang kemudian tercetak oleh printer point of sales sehingga tidak ada transaksi yang tidak dilaporkan sehingga dapat dikatakan membuat kepatuhan wajib pajak dalam membayar pajak semakin meningkat. Hasil penelitian ini memperkuat penelitian yang dilakukan (Pramasita \& Rasmini, 2018) yang menyatakan bahwa penerapan alat perekam transaksi sangat efektif dalam mengurangi terjadinya kecurangan terhadap pelaporan pajak. Karena tapping box mampu memberikan gambaran lebih detail terhadap jumlah pajak yang harus dibayarkan oleh wajib pajak akan berdampak signifikan terhadap penerimaan pajak daerah serta mendukung tindakan yang telah diterapkan oleh Badan Pendapatan Kota Denpasar bahwa pemonitoring scara online mampu meningkatkan kepatuhan wajib pajak dalam membayar pajak. 


\section{SIMPULAN}

Berdasarkan hasil analisis maka dapat simpulkan bahwa kesadaran wajib pajak berpengaruh positif pada kepatuhan wajib pajak membayar pajak restoran di Badan Pendapatan Daerah Kota Denpasar. Semakin tinggi tingkat kesadaran wajib pajak, maka pemahaman dan pelaksanaan kewajiban perpajakan semakin baik. Kualitas pelayanan berpengaruh positif pada kepatuhan wajib pajak membayar pajak restoran di Badan Pendapatan Daerah Kota Denpasar. Dengan kualitas pelayanan yang baik akan mendorong seseorang untuk memenuhi kewajibannya didalam membayar pajak. Sanksi pajak berpengaruh positif pada kepatuhan wajib pajak membayar pajak restoran di Badan Pendapatan Daerah Kota Denpasar. Semakin tegas pemerintah kota Denpasar dalam memperlakukan dan menerapkan sanksi maka wajib pajak akan semakin patuh dalam memenuhi kewajibannya. Penerapan alat tapping box berpengaruh positif pada kepatuhan wajib pajak membayar pajak restoran di Badan Pendapatan Daerah Kota Denpasar. Penerapan tapping box akan meningkatkan kepatuhan wajib pajak dalam membayar pajak.

Saran yang dapat disampaikan adalah pemerintah melalui Direktorat Jenderal Pajak melakukan dan memberikan sosialisasi berkesinambungan dengan penyuluhan tentang pentingnya manfaat pajak kepada masyarakat, sehingga dapat meningkatkan kepatuhan wajib pajak dalam membayar pajak, khususnya pajak restoran. Menerapkan dan menambahkan sanksi sosial berupa pemasangan bander atau baliho bagi wajib pajak yang melanggar dan tidak taat dalam memenuhi kewajibannya dalam membayar pajak restoran yang dapat membuat dan menambah efek jera bagi pelanggar. Penerapan alat tapping box berpengaruh positif pada kepatuhan wajib pajak restoran di Badan Pendapatan Kota Denpasar. Berdasarkan hasil penelitian tersebut, maka kedepannya diharapkan mampu memperbanyak penerapan alat tapping box.

\section{REFERENSI}

Denpasar, D. P. K. (2016). Laporan Akhir Kegiatan Belanja Modal Pengadaan Alat Tapping box. Jakarta: PT. Andromeda Multi Teknotaama.

Dewi, S. K., \& Merkusiwati, N. K. L. A. (2018). Pengaruh Kesadaran Wajib Pajak, Sanksi Perpajakan, E-Filing, dan Tax Amnesty Terhadap Kepatuhan Pelaporan Wajib Pajak. E-Jurnal Akuntansi. https://doi.org/10.24843/eja.2018.v22.i02.p30

Dewinta, R. M., \& Syafruddin. (2012). Pengaruh Persepsi Pelaksanaan Sensus Pajak Nasional dan Kesadaran Perpajakan terhadap Kepatuhan Wajib Pajak di Lingkungan Kantor Wilayah Direktorat Jenderal Pajak Daerah Istimewa Yogyakarta. Journal of Accounting, 1(2), 1-9.

Efferin, S., Darmadji, S. H., \& Tan, Y. (2008). Metode Penelitian Akuntansi. Yogyakarta: Graha Ilmu.

Febrianti, M. (2018). Faktor-faktor yang mempengaruhi realisasi penerimaan pajak bumi dan bangunan sektor pedesaan dan perkotaan di kabupaten Bangka Tengah. Jurnal Bisnis Dan Akuntansi. https://doi.org/10.34208/jba.v19i1.65

Freddy, R. (2006). Teknik Mengukur dan Strategi Meningkatkan Kepuasan. Pelanggan. Jakarta: PT Gramedia Pustaka Utama. 
Ghozali, I. (2009). Aplikasi Analisis Multivariate dengan Program SPSS (2nd ed.). Semarang: Badan Penerbit Universitas Diponegoro.

Hanousek, J., \& Palda, F. (2004). Quality of government services and the civic duty to pay taxes in the Czech and Slovak Republics, and other transition countries. Kyklos. https://doi.org/10.1111/j.0023-5962.2004.00252.x

Harahap, A. A. (2004). Paradigma Baru Perpajakan Indonesia. Perspektif. Ekonomi Politik. Jakarta: Integritas Dinamika Press.

James, S., \& Nobes, C. (1997). The Economics of Taxation, Principle, Policy and Practice. Europe: Prentice Hall.

Januarta, A. D. (2011). Pengaruh Kewajiban Moral, Kualitas Pelayanan dan Sanksi Perpajakan pada Kepatuhan Wajib Pajak dalam Membayar Pajak Kendaraan Bermotor (PKB) di Kantor Bersama SAMSAT Tabanan. Universitas Udayana.

Jotopurnomo, C., \& Mangoting, Y. (2013). Pengaruh kesadaran wajib pajak, kualitas pelayanan fiskus, sanksi perpajakan, lingkungan wajib pajak berada terhadap kepatuhan wajib pajak orang pribadi di Surabaya. Tax $\mathcal{E}$ Accounting Review.

Mardiasmo. (2016). Perpajakan Edisi Terbaru 2016. Penerbit ANDI.

Mustikasari, E. (2007). Kajian Empiris Tentang Kepatuhan Wajib Pajak Badan Di Perusahaan Industri Pengolahan Di Surabaya. Simposium Nasional Akuntansi X.

Nugroho, A., Andini, R., \& Raharjo, K. (2016). Pengaruh Kesadaran Wajib Pajak Dan Pengetahuan Perpajakan Wajib Pajak Terhadap Kepatuhan Wajib Pajak Dalam Membayar Pajak Penghasilan. Journal Of Accounting.

Pancawati, H., \& Rachmawati, M. O. (2012). Pengaruh Due Professional Care, Etika, dan Tenur Terhadap Kualitas Audit. Jurnal Fakultas Ekonomi Unisbank Semarang.

Pramasita, I. A., \& Rasmini, N. K. (2018). Pengaruh Kesadaran Wajib Pajak, Pengetahuan Pajak, Kualitas Pelayanan, dan Penerapan Alat Perekam Transaksi (Tapping Box) Pada kepatuhan Wajib Pajak Dalam Membayar Pajak Hotel di Badan Pendapatan Kota Denpasar. E-Jurnal Akuntansi, 5(1), 456-468.

Pratiwi, I., \& Setiawan, P. (2014). Pengaruh Kesadaran Wajib Pajak, Kualitas Pelayanan, Kondisi Keuangan Perusahaan, Dan Persepsi Tentang Sanksi Perpajakan Pada Kepatuhan Wajib Pajak Reklame Di Dinas Pendapatan Kota Denpasar. E-Jurnal Akuntansi.

Rahmani, A. F. (2014). Kepatuhan Wajib Pajak Masih Minim. Retrieved September 1, 2019, from http://www.republika.co.id/berita/ekonomi/makro/14/09/09/nble57kepatuhan-wajib-pajak-masih-minim

Sucandra, I., \& Supadmi, N. (2016). Pengaruh Kualitas Pelayanan, Pemeriksaan Pajak, Pengetahuan Perpajakan Dan Sanksi Perpajakan Pada Kepatuhan Wajib Pajak Restoran. E-Jurnal Akuntansi.

Sugiyono. (2016). Metode Penelitian Bisnis (Pendekatan Kuantitatif, Kualitatif, dan $R \mathcal{E D}$ ). Bandung: Alfabeta.

Supadmi, N. luh. (2011). Meningkatkan Kepatuhan Wajib Pajak Melalui Kualitas Pelayanan. Jurnal Ilmiah Akuntansi. 
Susilawati, K. E., \& Budiartha, K. (2013). Pengaruh kesadaran wajib pajak, pengetahuan pajak, sanksi perpajakan dan akuntabilitas pelayanan publik pada kepatuhan wajib pajak kendaraan bermotor. E-Jurnal Akuntansi Universitas Udayana. https://doi.org/ISSN: 2302-8556

Yadnyana, I. K., \& Sudiksa, I. B. (2011). Pengaruh Peraturan Pajak Serta Sikap Wajib Pajak Pada Kepatuhan Wajib Pajak Koperasi di Kota Denpasar. Buletin Studi Ekonomi, 17(2), 197-206. 